\title{
Insights on motor-manual tree felling in Germany, recent developments to ensure efficient operations in singletree selection harvest ${ }^{\star}$
}

\author{
Stephan Hoffmann ${ }^{1 * *}$ (D), Dirk Jaeger ${ }^{2}$ (D) \\ ${ }^{1}$ Chair of Forest Operations, University of Freiburg, 79085 Freiburg, Germany \\ ${ }^{2}$ Department of Forest Work Science and Engineering, University of Goettingen, 37077 Goettingen, Germany
}

\begin{abstract}
Despite an intensive mechanization trend in German forest operations since the early 1990s, many sites restrict the efficient implementation of fully mechanized harvesting systems. Trafficability and singletree selection harvest-based silviculture, focusing on high stem volume broadleaves, such as European beech, are the main limitations. Thus, motor-manual operations are still prevalent but need to be adapted to stay efficient and improve safety in a changing work environment. Recent developments of new felling techniques and aiding tools and advances in training and work organization improved occupational health and safety. Also, these achievements help to avoid log devaluation due to felling damages. The general digitalization trend did not ignore motor-manual operations either. Smartphone applications can already contribute to more efficient bucking, operation planning and fleet management. Yet, motormanual operations will remain cost-intensive, and expose worker directly to occupational hazards. Therefore, operations should take as much advantage of mechanized systems as possible for feasible and applicable silvicultural objectives.
\end{abstract}

Keywords: Occupational health and safety, forest worker, felling equipment, digitalization

\section{Introduction}

Fully mechanized harvesting systems are the synonym for state-of-the-art logging operations in the Western World and have replaced motor-manual work due to higher productivity, cost competitiveness, and increased occupational health and safety (Axelsson, 1998; Labelle et al., 2017). However, in Germany, a key industrialized country with high labor costs, approximately $40 \%$ of timber production is still realized by motor-manual and semi-mechanized operations.

Silvicultural systems of structured broadleaf forests, with large target diameters and a selective utilization, as well as trafficability restrictions due to terrain conditions, limit extensive mechanization (BMEL, 2017). Due to the high ecological value, and higher resilience towards biotic and abiotic disturbances than coniferous monocultures, political intentions further promote silvicultural systems towards mixed stands, focusing on old-growth trees and ecological structures, including standing, and lying dead wood (BMEL, 2019). Although such forest structures and silvicultural systems have always been part of the German multifunctional forest management concept (e.g. Sotirov et al., 2017), the share of such stand characteristics will become dominant compared to single-layered monocultures, which creates more operational restrictions for mechanized harvesting systems. Considering the progressing forest certification efforts, and other operational restrictions associated with climate change, the area of application for fully mechanized operations might even further decrease (Berendt et al., 2017) or at least need to be adapted to combined systems such as pre-felling and skidding in semi-mechanized operations at extended skid trail spacing (Volmer, 2018). It means that motor-manual works will remain prevalent within the German forest operation sector. Therefore, recent technical, but also organizational advancements took place to increase the efficiency of such operations.

The objective of the authors is to share some insights into these developments with a broader audience through this subject review. It aims to support silviculturists with the implementation of close-to-nature forest management systems, by promoting operational tools for efficient facilitation of singletree selection harvest.

\section{Felling equipment}

Usually, a primary focus on the technical stage of a motor-manual operation is given to the chainsaw itself. Although not the inventor of the chainsaw, through its worldwide appreciation by professional loggers and long history of technical landmarks, the German STIHL Corporation is a good example of how things have changed. With the development of the STIHL TYP A, which is a two-man operated chainsaw, weighing $46 \mathrm{~kg}$ with a rated power of $6 \mathrm{hp}$, tree felling was professionalized in 1929. Yet, a revolutionary change occurred just a short time later, with the introduction of the worldwide bestseller STIHL CONTRA in the year

\footnotetext{
${ }^{*}$ This study was partially presented in FETEC 2019

** Corresponding Author: Tel: +49 7612033754 E-mail: stephan.hoffmann@nibio.no 
1959, a one man operated saw, weighing just $12 \mathrm{~kg}$ at a rated power of $6 \mathrm{hp}$ (STIHL, 2018). Not long after, chainsaws were already marked as an outdated technology for professional use, and quickly replaced by early-stage harvesters in Scandinavia, reaching a market dominance in the Nordic regions already by the end of the 1980s (Axelsson, 1998). Yet, the era of motormanual tree felling did not vanish. In fact, all major chainsaw manufacturers continued technical developments to further improve ergonomics by weight optimization and vibration dampers, safety features such as quick stop chain brake and emission improvements through the catalytic converter and alkylate fuels (Thöny, 2007; Haim 2009; STIHL, 2018). These developments led to the creation of high-tech power tools such as the recently released STIHL MS 500i with electronic fuel injection (Höllerl, 2017a). Also, the continues further development of battery powered chainsaws, with higher power ratings and longer work cycles, qualifying them for professional use (Wiese, 2019), pinpointed that there is a flourishing market for chainsaws in modern forestry.

Besides the technical performance of chainsaws, also the PPE (personal protective equipment) has gone through very evolutionary stages in the recent decades. Until the 1950s, ordinary farm gear was worn during forest work, and not even the use of a simple helmet was standard. However, with upcoming safety awareness and regulations top-down from EU level since 1989, with last revision through the Regulation EU/2016/425 (European Parliament and Council, 2016), high tech forestry PPE was developed from boot to helmet, adapted to the needs of forestry professionals (Figure 1). Independent institutions such as the KWF (Kuratorium für Waldarbeit und Forsttechnik, Groß-Umstadt/Germany), started already in the year 1982 to test PPE not only according to legal regulations, but also according to its functionality and suitability for forestry work (Hartfiel, 2003). With a previous focus on cut protection only, the technical garments of forestry workers further improved in wear comfort. Light stretch materials, wear resistance and high visibility colors for safety improvements, and well adapted to work in difficult terrain at all weather (Hartmann, 2007), create healthier working conditions and a higher level of job satisfaction and performance.

Clear communication among forestry workers is a fundamental requirement for accident prevention, and to avoid $\log$ devaluation through felling damages caused by miscommunication within a felling team. Therefore, two-way radio headsets, integrated in the earmuffs of professional forestry helmets have become mandatory during motor-manual felling operations in many state forest enterprises, and are often combined with automatic emergency call systems (Schmidt-Baum, 2008). The latest generation make use of Bluetooth connections, avoiding the wiring beneath the work gear, further increasing work comfort, and thus performance efficiency (Höllerl, 2017b).

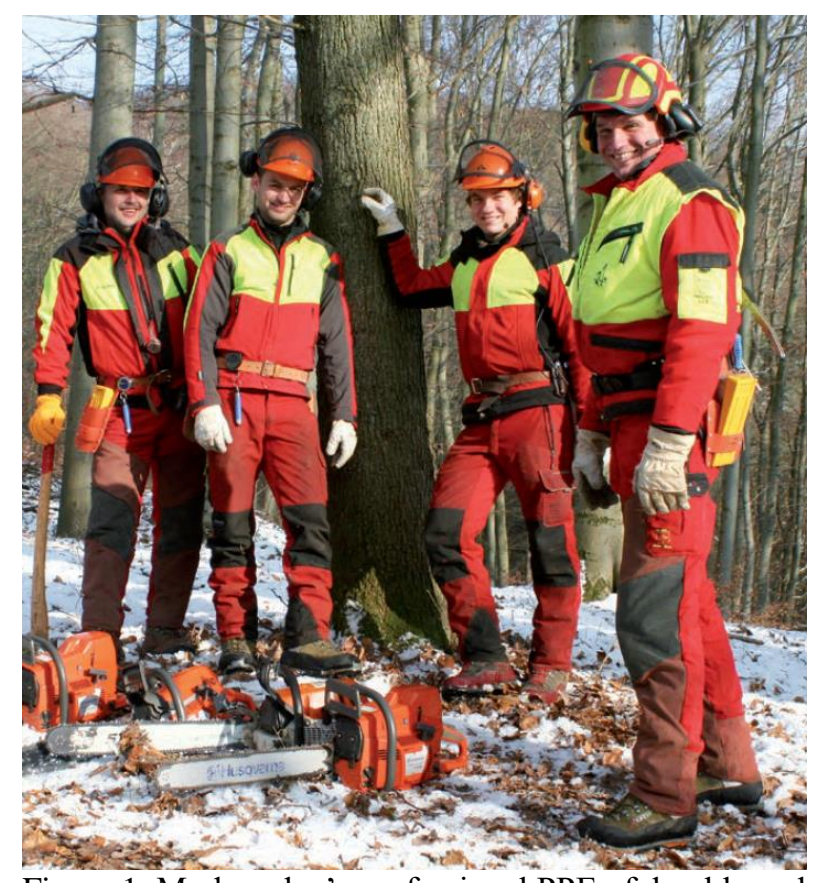

Figure 1. Modern day's professional PPE of durable and highly visible technical fabrics, with cut and weather protection, as well as high wearing comfort and modern communication devices such as earmuff integrated radios (Image: SVLFG, 2017)

Besides chainsaws and PPE, various felling aids in form of levers and wedges became essential equipment for motor-manual operations at high safety and performance levels. Particular felling wedges went through interesting stages of development in recent years. Light weighted PVC wedges are carried nowadays by every professional forest worker at his belt, supporting directional felling, but also securing the guide bar of the saw during felling cuts, avoiding chains getting stuck in the wood (SVLFG, 2017). More recently developed technical felling aids, such as hydraulic wedges and levers, increase these supports for high dimensional trees leaning opposite the felling directions. These technical felling aids have the additional advantage that work becomes more ergonomic, at lowered accident risk, for example caused by falling dead branches during conventional hammering (Ruppert, 2000). Top of the scale felling levers, such as the "Terminator" by Till-Hydraulik $\mathrm{GmbH}$, reach hoist forces of $34 \mathrm{t}$, allowing even difficult old growth felling in a selective manner, protecting the residual stand and natural regeneration (Nds. Landesforsten, 2014). However, with weights of around $10 \mathrm{~kg}$, these wedges and levers are quite heavy due to the hydraulic cylinders, creating ergonomic issues when moving in difficult terrain during logging operations. Therefore, much lighter, but at least in the normal range with up to $20 \mathrm{t}$ hoist power, almost equally powerful mechanical wedges have overtaken the application area (Höllerl, 2014). Although increasing the weight again, mechanical wedges are also available with refitted power tools, decreasing the manual force requirement for efficient application. The most recent development, the "TR300" 
by the company Forstreich $\mathrm{GmbH}$, fits a remote control on these wedges. This approach leads to the positive effects that a lower human force application is required, and that the forest worker can already retreat fully out of the risk zone in advance, since the final fall of the tree is conducted remote controlled with support of the wedge (Figure 2).

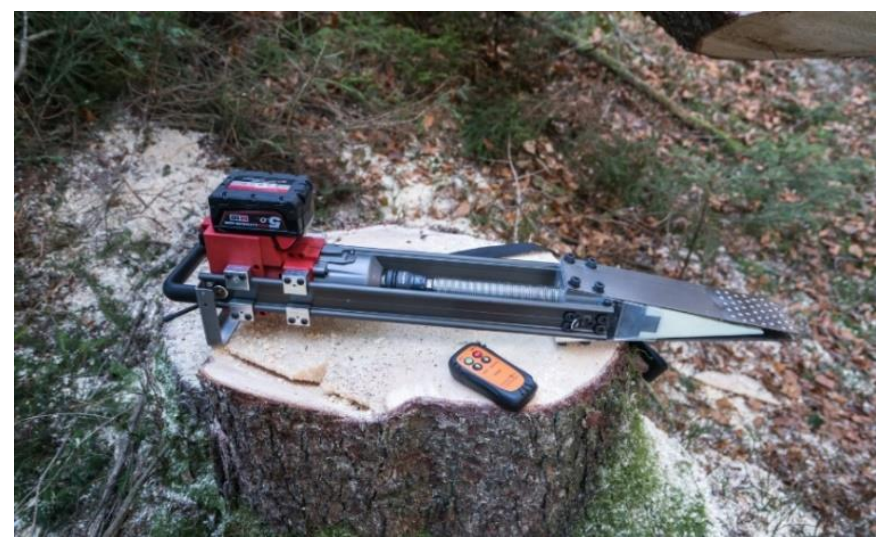

Figure 2. Remote controlled felling wedge Forstreich TR300

\section{Felling techniques}

Next to advances in equipment and gear, also felling techniques have further developed to guaranty the highest degree of safety and least devaluation of logs and residual stand resulting from felling damages. The international recognized standard felling technique (e.g., FAO, 1980), with a felling notch towards felling direction, a hinge for log guidance and a back cut for felling, was adapted in Germany in various ways to suit tree dimensions and felling situations. Most notably is the safety technique with a holding band, leaving full control to the feller until the point of tree fall, and was therefore defined as the new safety standard felling technique in Germany (SVLFG, 2017). Instead of an ordinary back cut, a bore cut is applied, leaving a holding band at the backside, which is quickly cut just after the worker is standing sideways in a safe retreating position (Figure 3). Since the weight of the log and crown creates tension, the tree can rupture without warning when applying the conventional standard felling technique, causing felling damages and in the worst-case fatal accidents. The holding band takes up the tension of the entire log and secures the tree until the end of the felling process, not putting the worker under any time pressure (DGUV, 2014; SVLFG, 2017).

The adaptation of felling techniques focused also on the inclusion of available felling aids. Therefore, special techniques were developed for the usage of felling levers or wedges, but also for cable supported felling techniques. The latter are special techniques combining chainsaw works with cable winches, further securing and guiding the falling direction of trees after an individual tree evaluation (Kieser, 2009). The wide availability of winches as tractor implements, or in form of flexible mini forestry crawlers (Tschannen, 2013), allow numerous applications of these techniques. Winch supported tree-felling increase the efficiency of thinning
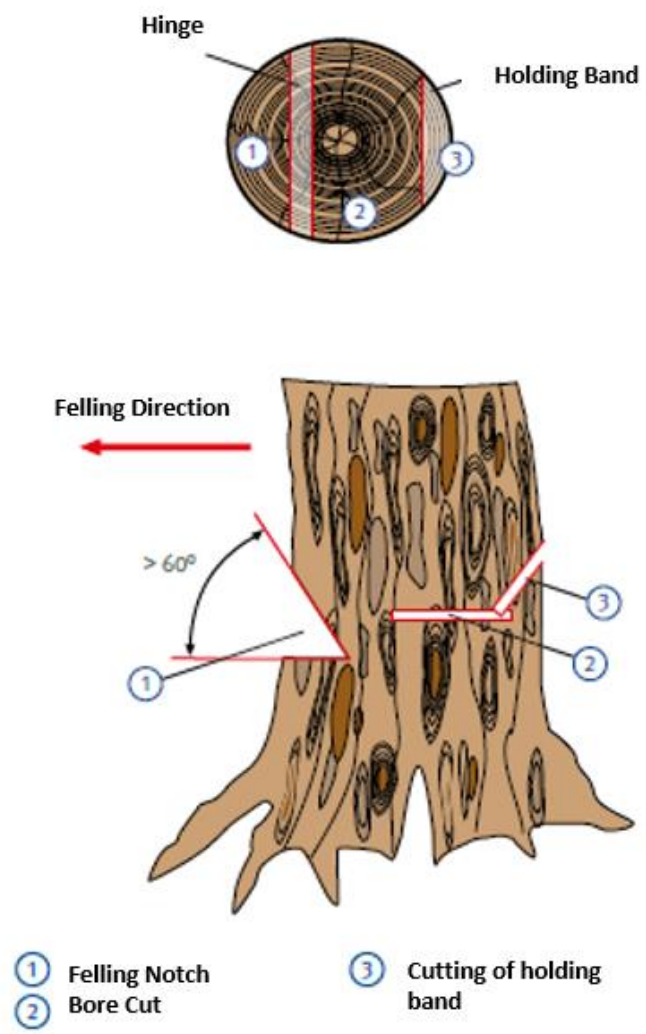

Figure 3. Safety felling technique with holding band (Image: DGUV, 2014, modified)

operations, which commonly creates hangers during felling. Also, within special tree felling in old growth stands, where trees are difficult to direct due to their wide crowns or other restrictions such as terrain, dead wood in crowns, harvesting in vegetation period or simply when structures deny the natural falling direction, winches are valuable supports (DGUV, 2014; SVLFG, 2017). The wide application of winch supported tree felling does not only create additional safety benefits, but also supports silvicultural treatments with low stand damages.

\section{Education and vocational training}

A professional and well-trained workforce is a key element for sustainable forest operations (Marchi et al., 2018). According to the German Vocational Training Act of 2005, with its last revision in 2017 (BMBF, 2005), forest worker (German "Forstwirt") is a recognized job qualification, requiring formal education and approved examination. Forest workers are trained in all requirements for efficient forest work through a three years lasting dual education, combining practical and theoretical expertise gained in a professional enterprise and governmental vocational training center.. This apprenticeship covers a wide range of subjects beyond pure chainsaw handling, such as forest management, timber harvesting, nature protection and landscape management, forestry equipment, enterprise organization and management (Forstwirtschaft in Deutschland, 2019). This guaranties a high standard during professional forest operations, enabling forest workers to implement silvicultural concepts by their daily activities. 
However, due to Germany's location within the mobile job market of the EU, characterized by international sub-contracting or just generally international staff among the enterprises, many forest workers active in German operations did not undergo these vocational qualifications. Therefore, measures are required to ensure a high-quality standard of operations and to fulfill the widely adopted certification requirements of employing only qualified staff (e.g., FSC, 2018). The European Chainsaw Certificate (ECC), initialized by the European Forestry and Environmental Skills Council (EFESC), is a European qualification standard for forest workers approving skills required for sustainable operations and is a mandatory verification for staff employed at public or certified enterprises in Germany (EFESC, 2017).

\section{Digitalization}

The ongoing digitalization of our modern world brought up applications under the umbrella of industry 4.0 , aiming to improve flexibility, productivity, and customer orientation of production, bearing high potential to increase the efficiency of wood supply chains, too (Müller et al., 2019). Owing the fact that chainsaws lack the connection to high-capacity on-board computers, as present with fully mechanized systems, motor-manual operations are far more limited to benefit from industry 4.0 applications. However, due to the prevalence of smartphones, the digitalization trend could also pursue in motor-manual operations. Already well established are i.e., smartphone apps for photo-optical timber scaling such as the iFOVEA ${ }^{\mathrm{TM}}$ system (FOVEA, 2019). Although not purposely developed for motormanual operations, such systems generally proved the relevance of smartphones in daily routines of forest work. For example, iFOVEA ${ }^{\mathrm{TM}}$ supports the German federal forest enterprise in all log pile measurements, thus being the interface to the log buyer for billing and all logistical processes.

More dedicated apps with a focus on increasing the efficiency of chainsaw operators are for example the recently released Tech4Effect Bucking App, increasing the value recovery of a log by optimized bucking (Erber et al., 2021), or the more sophisticated $\operatorname{LogBuch}{ }^{\mathrm{TM}}$ app. The latter, covers already the entire felling process from tree selection by the forester, setting a geo-reference of the selected tree's location and adding relevant information regarding safety hazards, optimal felling and extraction direction or other information through a headset voice recording and GPS magnifier (Eber 2019). This information can be provided to the chainsaw operator on his smartphone in form of a logging map for enhanced in-stand navigation. Schraitle (2018) verified within a case study of a singletree selection harvest, characterized by restricted visibility through intensive natural regeneration, that the application of $\operatorname{LogBuch}{ }^{\mathrm{TM}}$ reduced the overall work time demand for the chainsaw operator by $25 \%$, his required walking distance by $20 \%$ and increased the rate of finding trees marked for felling by $14 \%$. The next development stage of the app intends to incorporate the process of geo-referenced assortment conversion on log lists. Thereby, not only all relevant information for the skidder operator is provided, this process also accelerates the billing and marketing of the logs due to fast information forwarding, increasing the overall efficiency of the harvesting operation.

$\operatorname{LogBuch}^{\mathrm{TM}}$ enables the incorporation of operation related information flow, already provided for some time by software solutions of the leading machine manufacturers for fully mechanized equipment. There, software packages such as John Deere's TimberMatic ${ }^{\mathrm{TM}}$ and TimberManager ${ }^{\mathrm{TM}}$ (John Deere, 2019) allow communication among machines within the harvesterforwarder supply chain and the contractor's office, allowing efficient fleet management for enhanced production. Yet, the component of fleet management is lacking with $\operatorname{LogBuch}{ }^{\mathrm{TM}}$, which however is available through the equipment manufacturers themselves. Both, STIHL and Husqvarna, the globally leading chainsaw manufacturers are providing fleet management applications as a combination of machine mounted sensors and smartphone applications, monitoring essential data such as operating hours, fuel consumption and maintenance intervals, but also ergonomic factors such as exposure to vibration (Husqvarna, 2019; STIHL, 2019). This offers not only additional potential to reduce downtimes, it also allows to coordinate a fleet of motorized hand tools among working teams.

\section{Conclusions}

Motor-manual operations are still prevalent in Germany as an important tool within singletree focused silviculture management. It will predominantly remain the operational system of choice in terrain with low trafficability, high dimensional timber and for low and scattered cut volumes, as for example dominant in private woodlots of small size. Yet, it requires highly qualified workers to implement such silvicultural systems, and to perform efficient operations. Suitable work equipment, techniques, and organization, following the latest findings in ergonomics, occupational health, and safety, as well as environmental compatibility to do so, are available. But these operational components will also need frequent revisions if no alternative mechanized method suits the same requirements. The ability to capture, process and provide operation specific information through digital applications will have a significant contribution to that. Therefore, although motor-manual operations are currently the most adequate practice at many sites, where possible, the hazardous work of tree felling should be replaced by mechanized systems to further reduce occupational risks.

\section{Ethics Committee Approval: N/A.}

Peer-review: Externally peer-reviewed. 
Author Contributions: Concept: S.H.; Design: S.H.; Supervision: D.J.; Resources: S.H and D.J.; Data Collection: S.H and D.J.; Analysis: S.H.; Literature Search: S.H and D.J.; Writing Manuscript: S.H.; Critical Review: S.H and D.J.

Conflict of Interest: The authors have no conflicts of interest to declare.

Financial Disclosure: The authors declared that this study has received no financial support

Cite this paper as: Hoffmann, S., Jaeger, D. 2021. Insights on motor-manual tree felling in Germany, recent developments to ensure efficient operations in singletree selection harvest, European Journal of Forest Engineering, 7(1):39-44.

\section{References}

Axelsson, S.-Å., 1998. The Mechanization of Logging Operations in Sweden and its Effect on Occupational Safety and Health. International Journal of Forest Engineering 9(2):25-31.

DOI: $10.1080 / 08435243.1998 .10702715$

Berendt, F., Fortin, M., Jaeger, D., Schweier, J., 2017. How Climate Change Will Affect Forest Composition and Forest Operations in BadenWürttemberg-A GIS-Based Case Study Approach. Forests 8(8):298. DOI: 10.3390/f8080298

BMBF (Ed.), 2005. Berufsbildungsgesetz. BBiG, revised 7/17/2017. Edited by Bundesministerium für Bildung und Forschung http://www.gesetze-iminternet.de/bbig_2005/BBiG.pdf (Accessed: 19 November 2019)

BMEL (Ed.), 2017. Waldbericht der Bundesregierung 2017. Edited by Bundesministerium für Ernährung und Landwirtschaft. Bonn.

BMEL (Ed.), 2019. Forstwirtschaft in Deutschland. Edited by Bundesministerium für Ernährung und Landwirtschaft. https://www.forstwirtschaft-indeutschland.de/forstwirtschaft/forstwirtschaft-indeutschland/ (Accessed: 16 November 2019).

DGUV (Ed.), 2014. Sichere Waldarbeiten. Edited by Deutsche Gesetzliche Unfall Versicherung (DGUV Informationen, 214-046). Berlin

Eber, J., 2019. Motorsäge und App. Forst und Technik (7):20-23.

EFESC (Ed.), 2017. EFESC Handbook. Edited by European Forestry and Environmental Skills Council, KWF Groß-Umstadt/Germany. https://efesc.org/wpcontent/uploads/12_EFESC_Handbook_Nov_20171.pdf (Accessed: 19 November 2019).

Erber, G., Stelzer, S., Stampfer, K., 2021. Evaluation of a novel mobile device app for value-maximized bucking by chainsaw. International Journal of Forest Engineering (online first).

DOI:10.1080/14942119.2021.1927362
European Parliament and Council, 2016. Regulation (EU) 2016/425 of the European Parliament and of the Council on personal protective equipment. EU/2016/425. Official Journal of the European Union (L81/51).

FAO (Ed.), 1980. Chainsaws in Tropical Forests. Edited by Food and Agriculture Organization of the United Nations, Rome. 96 p.

Forstwirtschaft in Deutschland (Ed.), 2019. Der Forstwirt: Ausbildung und Arbeit. https://www.forstwirtschaft-in-deutschland.de/ forstwirtschaft/arbeitgeber-forstwirtschaft/forstwirtin/ (Accessed: 19 November 2019).

FOVEA, 2019. Digitale Holzvermessung. https://www.fovea.eu/ (Accessed: 21 November 2019).

FSC (Ed.), 2018. Deutscher FSC-Standard 3-0. $2^{\text {nd }}$ ed. Edited by Forest Stewardship Council Deutschland. Freiburg. https://www.fsc-deutschland.de/preview. fsc-waldstandard-3-0.a-1207.pdf (Accessed: 17 November 2019).

Haim, G., 2009. Von der Fällmaschine zur modernen Motorsäge. Wald und Holz 83(9):51-54.

Hartfiel, J., 2003. Arbeitsschutzausrüstung gestern und heute. Eine Entwicklungsgeschichte. Wald und Holz 84(8):64-67.

Hartmann, H., 2007. Funktionelle Bekleidung hält Einzug in den Forstbetrieben. Bündnerwald 60(2):16-19.

Höllerl, H., 2014. Kurbeln statt klopfen. Forst und Technik (12):14-18.

Höllerl, H., 2017a. Einspritzsäge. Forst und Technik (11):70.

Höllerl, H., 2017b. KuNo kabellos. Forst und Technik (11):69.

Husqvarna, 2019. Husqvarna Fleet Services. https://www.husqvarna.com/de/rasen-garten/profi/ fleetservices/ (Accessed: 19 November 2019).

John Deere, 2019. TimberMatic ${ }^{\text {TM }}$ Maps TimberManager ${ }^{\mathrm{TM}}$. Edited by Deere \& Company. https://www.deere.co.uk/assets/publications/index.ht ml?id=bd2a8bf9\#1 (Accessed: 21 November 2019).

Kieser, W., 2009. Fällen mit Seilwinde leicht gemacht! Forst und Technik (5): 2-5.

Labelle, E.R., Bergen, M., Windisch, J., 2017. The effect of quality bucking and automatic bucking on harvesting productivity and product recovery in a pine-dominated stand. European Journal of Forest Research. 136(4):639-652. DOI:10.1007/s10342017-1061-4

Marchi, E., Chung, W., Visser, R., Abbas, D., Nordfjell, T., Mederski, P.S., McEwan, A., Brink, M., Laschi, A., 2018. Sustainable Forest Operations (SFO): A new paradigm in a changing world and climate. The Science of the total Environment 634:1385-1397. DOI:10.1016/j.scitotenv.2018.04.084

Müller, F., Jaeger, D., Hanewinkel, M., 2019. Digitization in wood supply - A review on how Industry 4.0 will change the forest value chain. 
Computers and Electronics in Agriculture 162:206218. DOI:10.1016/j.compag.2019.04.002

Nds. Landesforsten, 2014. Fällheber Terminator. Im Praxistest bewährt. Forst und Technik (7):6.

Ruppert, D., 2000. Einsatz von hydraulischen Fällhilfen. Forsttechnische Informationen (5+7):49-50.

Schmidt-Baum, T., 2008. Konzepte für Rettungsketten in Waldarbeitssystemen. 1st Edition, Cuvillier, Göttingen. 282 p.

Schraitle, M., 2018. Geolokalisation der Erntebäume in naturverjüngungsreichen Beständen mit LogBuch. Hochschule für Forstwirtschaft, B.Sc. Thesis, Rottenburg.

Sotirov, M., Blum, M., Storch, S., Selter, A., Schraml, U. 2017. Do forest policy actors learn through forwardthinking? Conflict and cooperation relating to the past, present and futures of sustainable forest management in Germany. Forest Policy and Economics 85:256-268.

DOI:10.1016/j.forpol.2016.11.011

STIHL, 2018. Annual Report 2018. Tradition and Transformation. Edited by STIHL Holding AG \& Co. KG. Waiblingen.https://ar2018.stihl.com/downloads/
STIHL_AnnualReport2018_EN_Web.pdf

(Accessed: 19 November 2019).

STIHL, 2019. STIHL Smart Connector. Produkte intelligent vernetzen. Edited by STIHL Holding AG $\& \quad$ Co. KG. https://www.stihl.de/STIHLProdukte/Smarte-L\%C3\%B6sungen/287476-93994/ Produkte-intelligent-vernetzen.aspx (Accessed: 16 November 2019).

SVLFG (Ed.), 2017. Waldarbeit. Aktuelles zu Sicherheit und Gesundheitsschutz. Edited by Sozialversicherung für Landwirtschaft, Forsten und Gartenbau, Kassel. 87 p.

Thöny, P., 2007. The History of the Chainsaw. https://www.waldwissen.net/lernen/forstgeschichte/ wsl_geschichte_motorsaege/index_EN (Accessed: 21 November 2019).

Tschannen, W. 2013. Ferdi Nussbaumer und sein „RaupTrac". Der 1-Maschinen-Forstunternehmer. Wald und Holz (8):51-53.

Volmer, J. 2018. Fach-Seminar in Neheim führt bewährte Praxis und neue Ideen zusammen. Forsttechnische Informationen 70(6):5-6.

Wiese, P. 2019. Akkugeräte im Forst. Forst und Technik (9):20-25. 